\title{
EDITORIAL
}

\section{Editorial note: welcome to Volume 22 and the year 2019}

On behalf of the Editorial Board of the African Journal of Nephrology (AJN), I wish all readers, contributors and reviewers a happy and successful 2019. We have successfully completed our third year as an online Journal. We sincerely thank everyone who contributed to this achievement. With your support, we will achieve more milestones.

I wish to take this opportunity to remind all our readers and contributors that AJN is the official journal of the African Association of Nephrology (AFRAN).

During 2019, AFRAN, in partnership with the Kenya Renal Association, will convene its biennial congress in Mombasa, Kenya, from 25-29 September. Let us give Professor Were, AFRAN President-Elect, and the Kenya Renal Association all the support they need. Through our participation, we will ensure that the AFRAN congress is a great success.

This year, the nephrology calendar is fully loaded. Besides various local and regional congresses, including the AFRAN Congress, at the global level the World Congress of Nephrology will be held in Melbourne, Australia, from 12-15 April 2019. World Kidney Day is also fast approaching. It will be celebrated as usual, on the second Thursday of March, 14 March 2019. The theme this year is "Kidney Health for Everyone Everywhere".

In Volume 21 in 2018, AJN published excellent original articles from various regions of Africa, including East, West and Southern Africa. The proceedings of the 2018 South African Renal Congress are also part of AJN Volume 21. Of note, also in Volume 21, the publication of the 2016 South Africa Renal Registry Annual Report gives a picture of renal replacement therapy in an African country.

In 2019, in Volume 22, AJN expects to continue to publish excellent original articles as well as review articles to display research outputs from our contributors. We invite researchers to continue to submit their best work, and nephrology societies to submit the proceedings of their local and regional congresses.

Once again, Happy 2019 and we look forward to seeing you in Melbourne in April and Mombasa in September! KARIBUNI SANA AFRAN Congress in Kenya!

\section{Alain G Assounga \\ Editor-in-Chief}

